\section{Magnús Karl Magnússon}

prófessor og forseti

læknadeildar Háskóla Íslands

\title{
Læknaskóli í 140 ár
}

Upp úr miðri 19. öld var heilbrigðispjónusta í okkar fátæka og afskekkta landi með nokkuð öðrum brag en nú pekkist. Læknaskortur var mikill. Prátt fyrir að fyrsti íslenski landlæknirinn, Bjarni Pálsson, skipaður 1760, hefði með miklum dugnaði menntað íslenska lækna samhliða öðrum störfum var ástandið tæpri öld síðar pannig að enginn stundaði læknanám á Íslandi og fáir Íslendingar lögðu land undir fót til að nema læknisfræði og enn færri sneru heim með gráðu í farteskinu. Pannig segir Vilmundur Jónsson í formála Læknatalsins hins fyrsta að prátt fyrir að „stjórnvöldin ívilnuðu að ýmsu leyti Íslendingum er leggja vildu stund á læknanám ytra, varð eftirtekjan ekki meiri en svo að einir 12 luku læknaprófi í Kaupmannahöfn fyrstu sex áratugi aldarinnar, og af peim ílentust fjórir ytra“. ${ }^{1}$ Nýendurreistu Alpingi var ljóst að ekki yrði gerð bragarbót á pessum mikla læknaskorti nema með endurreisn læknakennslu innanlands. Jón Thorstensen páverandi landlæknir sýndi innlendri læknakennslu lítinn áhuga. Раð urðu pó straumhvörf pegar Jón Hjaltalín (1807-1882) tók við embætti landlæknis árið 1855. Hann beitti sér fyrir pví að Alpingi sampykkti bænaskrá til konungs um stofnun læknaskóla á Íslandi. Pegar peirri beiðni var hafnað gafst Jón Hjaltalín ekki upp og sótti fast að taka upp eldri sið og fá leyfi til pess að landlæknir mætti mennta unga sveina til læknaprófs. Árið 1862 fékkst leyfi konungs og hófst pá uppbygging læknanáms með fjölbreyttu og metnaðarfullu námi, par sem kennd voru meðal annars líkskurðarfræði (anatomie), lífseðlisfræði, sjúkdómafræði, handlæknisfræði, yfirsetukvennafræði, chemie, heilbrigðisfræði, meðalaverkunarfræði og fleiri greinar. Petta metnaðarfulla starf Jóns Hjaltalíns sýndi fram á getu Íslendinga til að mennta lækna og á næsta hálfa öðrum áratug lögðu 13 ungir menn stund á nám og útskrifuðust sem kandídatar. Með pessu varð gerbreyting á stöðu mála miðað við hina fyrstu 6 áratugi aldarinnar. ${ }^{1}$

Í ljósi pessa brautryðjendastarfs Jóns landlæknis Hjaltalín var konungi ekki lengur stætt á að neita kröfum Íslendinga um stofnun Læknaskóla. Árið 1876 var Læknaskóli Reykjavíkur pví stofnaður með konungsbréfi. Nú eru pví 140 ár liðin frá stofnun læknaskóla á Íslandi og eru fáar stofnanir sem hafa blómstrað jafnlengi í okkar samfélagi og gefið af sér jafn ríkulegan ávöxt. Í upphafi voru ráðnir prír kennarar. Auk Jóns, sem veitti skólanum forstöðu, voru ráðnir Jónas P. Jónassen (1840-1910) og Tómas Hallgrímsson (1842-1893). Fyrstu árin var skólinn rekinn í Sjúkrahúsi Reykjavíkur við enda Aðalstrætis en flutti síðar í Pingholtin (í hús er nú kallast Farsóttarhúsið). ${ }^{2}$ Metnaður var mikill en stundum var erfitt að fá pann efnivið er til purfti. Pannig var ávallt skortur á líkum til líkskurðarkennslu og er fræg sagan af Pórði malakoff Árnasyni, pekktum brennivínsberserk í borginni sem seldi lík sitt Læknaskólanum með fyrirframgreiðslu og tórði svo árum saman læknanemum og kennurum skólans til nokkurs ama. Er Pórður malakoff loks dó árið 1897 var umtalað að læknanemar hafi tekið svo „sleitilega og frómlega“ til verks að dómkirkjuprestur hafi flutt líkræðu yfir nánast tómri kistunni. ${ }^{3}$ Á peim 35 árum sem Læknaskólinn starfaði jókst kennarafjöldinn úr premur í 8 og alls útskrifuðust 62 kandídatar frá skólanum. ${ }^{2}$ Læknaskóli Reykjavíkur var síðan ein grunnstoð í stofnun Háskóla Îslands árið 1911 og hófst pá nýr kafli í læknanámi á Íslandi.

Á peim 140 árum sem liðin eru frá upphafi læknanáms á Íslandi hefur mikið breyst. Á pessu afmælisári læknanáms er að hefjast heildarendurskoðun á læknanámi til að bregðast við auknum kröfum um gæði náms og til að undirbúa nýja kynslóð lækna fyrir pær fjölmörgu áskoranir sem við okkur blasa. Í nýlegri sjálfmatsskýrslu deildarinnar voru greind pau atriði í náminu sem bæta má en jafnframt komu í ljós atriði sem læknadeild getur verið stolt af. Vel yfir $90 \%$ nemenda eru í heildina ánægðir með nám sitt. Íslenskir læknar eiga greiða leið í sérnám til bestu sjúkrahúsa austan hafs og vestan. Nemar okkar taka bandarískt stöðupróf í lok náms (Comprehensive Clinical Science Examination - CCSE) og ná frábærum árangri, skora að meðaltali 80-82 stig en meðaltal bandarískra læknanema á lokaári síns náms er 75 stig. Fjölbreytni kennarahópsins er mikil, læknar og aðrir vísindamenn deildarinnar hafa menntað sig við bestu stofnanir beggja vegna Atlantsála. Getur pví deildin verið gífurlega stolt af sínum nemum og kennurum. Endurskoðun á læknanámi mun leitast við að tengja enn betur saman grunnnám og klínískt nám, auka verulega á fjölbreytni kennsluaðferða, auka möguleika á rannsóknarnámi, svo sem samtengdu lækna- og doktorsnámi. Einnig verður hugað að pví að mennta enn frekar pá lækna sem samfélagið parfnast, svo sem með aukinni áherslu á heilsugæslu, persónumiðaða læknisfræði (personalized eða precision medicine) og heilsu aldraða.

Í nútímasamfélagi gegna háskólar lykilhlutverki við menntun, vísindi og nýsköpun. Um leið eru peir undirstaða framfara. Í samfélaginu er rík og sívaxandi krafa um öfluga háskóla. Læknadeild Háskóla Íslands tekur petta fjölpætta hlutverk sitt mjög alvarlega. Á pessum tímamótum í læknanámi á Íslandi væri engin betri afmælisgjöf en að stjórnvöld vöknuðu úr dvala og svöruðu ákalli háskólayfirvalda og samfélags um stóraukin fjárframlög til að tryggja komandi kynslóðum gæðamenntun sem mun tryggja heilsu, hamingju og hagsæld til framtíðar.

16. desember næstkomandi verður pessara tímamóta minnst með málpingi og móttöku í Háskóla Íslands og eru læknar, starfsmenn deildarinnar og aðrir velunnarar hvattir til að mæta.

\footnotetext{
Heimildir

1. Jónsson V. Læknar á Íslandi (Inngangur) (önnur útgáfa). Læknafélag Î́lands/ Ísafoldarprentsmiðja, Reykjavík 1952.

2. Ásmundsson P. Síðustu kennarar Læknaskólans í Reykjavík. Læknablaðið 2015; 101: 281-2. 3. Friðriksson G. Pórður malakoff. Lesbók Morgunblaðsins 1992 (11. apríl) 15. tölublað.
} 